\author{
Anna Szyjkowska-Piotrowska \\ Academy of Fine Arts in Warsaw \\ Fryderyk Chopin University of Music, Warsaw \\ anna.szyjkowska-piotrowska@cybis.asp.waw.pl
}

\title{
THE ART OF PARTICIPATING IN SILENCE
}

\begin{abstract}
The purpose of the essay is to use associations related to silence in order to ascertain whether "participation/participation in silence" is in fact an oxymoron. First, the reflection focuses on the possible meanings of silence. The author proposes treating silence as a performative (non)act of speech. She then uses the criteria developed by J.L. Austin to demonstrate the performative and abstract (and therefore not narrative or descriptive) nature of silence. Secondly, the expression "participation in silence" is considered in the light of Aristotle's views on the individual-community axis. Finally, earlier reflections are used to identify the links between silence and art. John Cage's 4'33 is a selected example, though not the only one. It turns out that participation in silence is not an oxymoron.
\end{abstract}

Keywords: silence, art, participation

Il faut également souligner le rôle du silence, de ce que l'on pourrait appeler le silence coloré, pour reprendre une expression du langage cinématographique, grâce auquel on entend jusqu'à leur extinction les résonances des accords ${ }^{1}$.

I am going to start with a rather intuitive outline of my first associations with this somewhat surprising combination of "participation" and "silence". Later, I intend to bring out their connections to art, revealing that the contradiction might be a signum temporis rather than a question of conflict between the notions themselves.

1 Jean-Ives Bosseur, Pierre Michel, Musiques contemporaines: perspectives analytiques, 1950-85, Minerve, Paris, 2007, p. 28. 
What is new to art is not always new to culture. Silence as a means of communication; silence marking an important event; silence as a tribute, as a sign of respect, as mourning; silence as an answer; silence as a means of exercising power, as a passive-aggressive tool to have one's way. There have been different types of silence since the beginnings of culture. In trying to search for common ground between these types, one can reach the conclusion that when silence is used as a tool, its power lies especially and mostly in its ambiguity. At the same time, silence that is used not as a performative tool but as a way of bettering the self, usually connected to spiritual beliefs, also seems to rely on ambiguity and its elusive, unattainable character. The presence of restriction in this act of nonact (that is not speaking instead of uttering a sentence) brings experience of it to the realm of the spiritual; it opens possibilities of an 'exercise of the self'.

Silence is a rainbow of possible meanings. Anyone aggressed (sic!) by means of silence, by another person who is thereby closing the path to explicit communication, will probably admit that such a situation placed him - by force - at the peak of his interpretative possibilities. While recollecting this experience he will probably admit that it is like turning round and round in an effort to choose the right color of interpretation. The clues can be found - so to speak - outside this silence, in the context of the before and the after. It is therefore accessories connected to the silence or what preceded it and what will come later that can help frame silence in our mind.

Thus, silence itself is already like a piece of art that demands the utmost and strained hermeneutic effort of interpretation in some of its instances.

Silence has also a linguistic aspect, since just as saying something is meaningful, not saying something is meaningful in its own way. J. L. Austin could have been the perfect author of How to Do Things with Silence, seen the significance and impact of his revelatory (especially for performative studies) How to Do Things with Words. In such an imagined publication devoted to silence as a performative non-speech act or a "à rebours speech act" Austin could have showed us the spectrum of meanings of silence. We can use Austin's optics to view silence in terms of the performative speech acts. We will find that he focuses on the following:

- performative speech acts do not have a descriptive character;

- they are not actual statements;

- they rather aim at producing certain effects in the recipient, in reality or in the utterer.

As Austin himself puts it, the conditions are:

A) they do not 'describe' or 'report' or constate anything at all, are not 'true' or 'false'; and 
B) the uttering of the sentence is, or is a part of, the doing of an action that would again not normally be described as, or as 'just' saying something ${ }^{2}$.

A question that may come to mind is whether in adopting Austin's views on statements and performative acts to the phenomenon of silence - taken here in its linguistic nature - one should differentiate analogically between silence that 'acts' and silence that purely 'is'.

The first condition of differentiation between performative speech acts and statements is that the former do not 'describe', 'report' or constate. Here, however, the condition cannot be applied to differentiation between silence types since silence does not 'describe', 'report' or constate. I would say that silence is non-figurative; it is not illustrative or narrative as words and utterances can be and so it does not qualify for the first condition. Silence seems to be a pure abstract.

The second condition, however, seems much more adequate for considering silence as a performative act. Being silent can be a way of performing an action and being silent can also be more than just not producing sounds.

In different situations we have an implicit right to silence. Who has not heard the famous: "You have the right to remain silent" (hopefully only in a movie). Nevertheless, sometimes silence is the opposite of "the right". It can be enforced and imposed on someone just as it had been the case with the women's vote for centuries. Having no right to speak up - in terms of a kind of performative 'yes' or 'no' - women fought for the right not to stay silent. In their staying silent about certain matters there was no solidarity or a meaning that they would ascribe to this kind of silence. The meaning came from outside and was oppressive.

I have recently participated in a round of voting among scholars and the question that arose was: how to understand the fact that someone abstained from voting. This form of silence has tangible, vivid consequences. There were voices that if one abstains in such a vote (which actually concerned art theory issues), she or he demonstrates to be unqualified to speak as an expert. Others said that it is a question of not wanting to participate in a given group or in a given situation. In a situation that can be larger than the vote itself. It is a sign of fundamental disagreement with what happens but it also implies the lack of sense of belonging, and a lack of will to participate. It is an expression of such an extent of disagreement that taking position becomes impossible. These two interpretations are usually the two mains, and conflicting, ways of interpreting someone's abstention from voting, into somebody's "vote-silence" as we could

2 J. L. Austin, How to do things with words, Harvard University Press, Cambridge Massachusetts, $1962 / 75$, p. 5. 
name it. There is a basis to take such a person for an ignorant that is not responsible and/or able to exercise her or his rights - it is an uncivic approach. Whereas the "vote-silence" person usually argues that she or he does not identify with the situation at all. Under such circumstances silence expresses the lack of will to participate.

Here, however, I will be interested in silence that does not build walls between the one that stays silent and the one that gets immersed in this silence or in silence that is imposed on the person to exclude from a community, to force a given person to stay shut in the world of necessities - in oikos. I am interested in silence that is not a performative tool in one way or another, but in silence that can be shared.

How can we share silence? How can we participate in it? Do we share silence just as we share drink or food? Or maybe sharing silence is similar to sharing rain - it surrounds us and falls down on us. But we do not produce the rain - whereas we can produce silence. Just that we do it by non-doing, by restriction. And this path of restriction - sooner or later - shall lead us to the silence of monks, Buddhists, but not eremites since the task I have given myself here is to reflect on the possibility of participating in silence. Thus, a group of purposefully silent people is needed as a case to study.

The problem that I encounter, however, while thinking about the practices of silence in monasteries - and in fact not only in monasteries but rather whenever this practice is at stake in all religions, all spiritual paths - is that something that looks like an oxymoron at a first glance is unavoidable here. Participating in silence is about finding solitude in community. Even silence that is not used in an oppressive way is ambivalent in meaning, since by definition it is neither verbal nor visual. It is audible in a certain sense, but audible as a 'lack'. Solitude is in it as a reflex to turn one's senses inside since there are no explicit stimuli. Silence, however, is a powerful implicit stimulus that leads to the activation not so much of the senses but rather the sensus communis - Aristotelian meta-sense that is not just focused on some particular perceptions but unites them, enabling the inner feeling of the whole. Having devoted some place to reflection on the role of silence I feel also the need to question my understanding of the notion of 'participation'. What does participation mean on the level of individual - community dialectics? And how to combine participation and silence especially in the realm of politics, which seems to require community as a ground, target and condition. Is it not that silence excludes participation, as we have seen in the example of voting?

In a conundrum like this, it a relief to turn to the old masters of philosophy, such as Aristotle. To simplify matters, I will go straight to the axis individual - community. In Nicomachean Ethics and Politics, we encounter a construction wherein society is based on the individual. The starting point is 
an individual because a good social life and a virtuous life of a community start with an individual. Aristotle enumerates what an individual has to be in order to lead a good life. What is most interesting here is that for Aristotle, the outcome of such a good individual life is participation in the community, in the polis. The practice of the virtues takes the most important place in the construction of an individual and consequently in the construction of the community in the view of Aristotle. Such interdependence with the focus on an individual seems to be absent from contemporary politics. What is more, today it sounds like a rather nad've idea of an idealist teenager. The concept of an individual who has to practice virtuous life in the solitude of his/her own heart and mind in order to add to the life of the community and to form polis with others of the same moral standing serves as a solution to the conundrum of solitude in a community. A certain degree of solitude seems beneficial and necessary in order to form the right community. And if it is to be a community of individuals at all, they need to be formed, they need to become individuals in themselves. "Through participation within the polis individuals can practice the virtues that bring about eudaimonia. Aristotle regards the polis as a natural phenomenon, which exists to promote the happiness of all as identified by individuals thro-

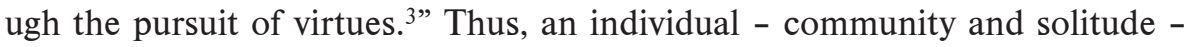
community seems to work in Aristotle's polis no worse than in communities of monks where the concentration on the interior almost seems multiplied by the number of bodies in silence.

Let us think of an experience shared by most students - studying in a library. It seems to me that silence and concentration of others provides an obstacle to temptations such as eating something 'illegally' underneath the table, whispering to a friend sitting next to you, letting tiredness and boredom take control or passing on to other activities. Others immersed in silence and contemplative concentration become a motivation. Just as bodies in common motion seem to become one, somehow this common silence also pushes to become one. Not one body, however, because the focus is on mind. But not one mind because each is still monadic in its character. What is this feeling of oneness then? Is it not somehow spiritual even in this little or vast library room? A nice feeling of thoughts flowing at the same time from centuries and from every corner of the room.

A feeling of a shared spiritual moment can also of course be present in religious rituals: during common prayer when at some point everyone stays silent, for example. Thus, it seems that sharing silence is indeed possible. One can participate in it.

3 Sally Wheeler, Corporations of The Third Way, Hart Publishing, Oxford, Portland, Oregon, 2002, p. 67. 
How does it all translate now to the field of art? There are several moments here when focusing on silence triggers associations with art. In the first I realized that silence is itself like an artwork in that it often demands a strenuous work of interpretation. I could add to it now that on other occasions, when it does not (rather offers a possibility of immersion), it enables the feeling of a spiritual journey into oneself and a feeling of transcendence which also brings it close to the sublime sought after in art. In the second point I stated that silence is abstract since it does not have illustrative or narrative characteristic. And the third point, I would like to make by saying that performative power of silence certainly offers a great potential for art. It is interesting to notice that in art since the avant-gardes participation and performative potential have become an integral part of the creative process. It is even more interesting to note just as visual arts and music sought their analogies since the 1950s, silence and black abstraction became one of them. It makes us think of the black canvasses of Robert Rauschenberg or Ad Reinhardt. But this fascination with the silent, the void, the black was not limited to visual arts only. Other examples include Samuel Beckett's Waiting for Godot or John Cage's 4'33.

The more I think about it, the more I realize that participation is crucial to silence in one way or another. Silence demands a receiver. Another crucial aspect is context. In the archives of artists' books in Rennes I stumbled upon a vinyl composed of the most significant silent moments in the history of music. Of course, it included John Cage's 4'33. The back cover indicated the division of silence into time and titles (titles of the songs from which the right amount of silence was taken). I believe that this artistic project shows in a very adequate way that silence is constructed in contrast to what precedes or - as in the case in Waiting for Godot and 4'33 - by anticipation. We are not really considering an absolute silence here. It is rather a culturally constructed silence. The title of a piece of silence seems to me analogically stimulating to imagination as a title of an abstract canvas.

Silence used in art may have some different characteristics than the examples I have depicted, what would these characteristics be? In the example of John Cage's 4'33, the artist himself ascribed meaning to this silence through his associations. He believed that the exaggerated grandeur of symphonic pieces was connected to the Second World War. He was opposed to the acceleration of media, which provokes consumerism. Douglas Kahn states that what made Cage defend the discreet and modest sounds of Erik Satie's music finally pushed him to the manifesto of silence ${ }^{4}$. Kahn highlights the fact that Cage's

4 See : Douglas Kahn, "Plénitudes vides et espaces expérimentaux. La postérité des silences de John Cage" in : Sons et Lumiéres, Centre Pompidou, Paris, 2004, p. 79. 
'silences' appear at the moment of the peak - according to many specialists of Western sophisticated music. Another silent piece by Cage is Silent Prayer which shows again how imposing the connection of silence and spirituality is. In fact, it is his first silent piece, composed in 1948.

When we think about the pianist David Tutor who sat in front of the piano and did not play during the indicated time, does this situation seem analogical to refraining from voting in this manifesto of the artist? Is it similar to imposing an oppressive silence on someone? Or is it a way to listen to silence together to participate in it? Not doing something has an explosive meaning especially in a situation in which one is 'meant to'. It was not absolute silence in the end. The audience participated rather in hearing out and paying attention to what they normally do not listen to with 'aesthetic hearing'. Kahn draws attention to the shift, often analyzed by critics when writing about Cage, from silence as absence to silence as plenitude, fullness (connected to the impossibility of the absence of sound). If we trust the critics or as I feel now, my own intuition, Cage's silence was only a silence as absence as a passage to get to the silence as plenitude. This plenitude in the case of this piece is searched for in the accidental sounds outside. If we think however about Cage's interest in philosophies and in self-perfection through self-observation, this plenitude could be rather interiorized. I have chosen to focus on a musical example but in visual arts the connection to silence was also present. It was in many ways a consequence of the avant-gardes' search to rejuvenate the idea of Gesamtkunstwerk. Just as Klee, Mondrian, Kandinsky, Kupka and many others would become inspired with sounds of music, silence could also be a source of inspiration for visual experiments and/or spiritual search.

It seems that the 'oxymoron' of solitude in community (solitude of choice positively marked therefore) is an important basis for language, politics and art. The movement from the individual to the common and back is the condition of any sense in it. Thus, it turned out that the 'oxymoron' is not an oxymoron but rather an ideal situation we might have forgotten to pursue. We might have forgotten it in politics but in language and art this tension still seems well preserved.

For Plato, participation concerned the world of ideas. Thus, any person or object participated on the higher ontological level - in the realm of ideas that were the source and the goal - arche and telos. Today, however, we seem rather unsure of participation with a vertical axis that would make us participate in a higher Being, even if this Being is only silence. Contrary to Cage's hopes, we still compulsively shut out the silence by means of our electronic devices that let us enjoy the buzz of words all the time. It seems to us that we participate in relations but we often forget the fundamental relation that can bring us to community - which is as Aristotle believed - the relation with oneself not only 
based on satisfying immediate pleasures but also on strengthening persistence in view of the 'lack of' which actually will never cease to be part of our lives. We seem to understand silence in a negative way, as a hostile lack, whereas it may also be plenitude found in absence.

\section{BIBLIOGRAPHY}

Austin John L. (1962/75) How to do things with words, Cambridge Massachusetts: Harvard University Press.

Bosseur Jean-Ives, Michel Pierre (2007) Musiques contemporaines: perspectives analytiques, 1950-85, Paris: Minerve.

Kahn Douglas (2004) "Plénitudes vides et espaces expérimentaux. La postérité des silences de John Cage" [in:] Sons et Lumiéres, Paris: Centre Pompidou.

Wheeler Sally (2002) Corporations of The Third Way, Oxford, Portland, Oregon: Hart Publishing.

\section{SZTUKA PARTYCYPACJI W CISZY (streszczenie)}

Artykuł w formie eseistycznej ma na celu użycie skojarzeń związanych z ciszą, aby sprawdzić czy „partycypacja/uczestnictwo w ciszy” w istocie jest oksymoronem. Najpierw tematem refleksji stają się możliwe znaczenia ciszy. Autorka proponuje traktowanie ciszy jako performatywnego (nie)aktu mowy. Używa następnie kryteriów wyłonionych przez J. L. Austina, aby ukazać performatywny i abstrakcyjny (a zatem nie narracyjny lub opisowy) charakter ciszy. W drugim rzędzie, wyrażenie „partycypacji w ciszy” zostaje przemyślane w świetle poglądów Arystotelesa dotyczących osi jednostka - wspólnota. Na końcu wcześniejsze refleksje zostają użyte do wydobycia powiązań ciszy ze sztuką. Wybranym - choć nie jednym - przykładem jest 4'33 Johna Cage'a. Okazuje się, że uczestniczenie w ciszy nie jest oksymoronem.

Słowa kluczowe: cisza, sztuka, uczestnictwo, partycypacja 